\title{
Influence of Ash and Coconut Shell Against Compressive Strength and Permeability Characteristics of Pervious Concrete
}

\author{
Suwendy Arifin ${ }^{\mathrm{a}}$, Oki Setyandito \\ a,b Civil Engineering Department, Faculty of Engineering, Bina Nusantara University, Jakarta, Indonesia 11480 \\ b okisetyandito@binus.ac.id
}

Article History: Received: 10 November 2020; Revised 12 January 2021 Accepted: 27 January 2021; Published online: 5 April 2021

\begin{abstract}
Pervious concrete or non-fine concrete is a simple form of lightweight concrete made by eliminating the use of fine aggregates. As a result of not using fine aggregate in pervious concrete, then created a cavity filled with air and water can be passed. This cavity resulted in reduced density of the concrete as well as the reduced amount of area that needs to be covered by cement paste, thereby reducing the compressive strength. To increase the compressive strength of pervious concrete, in this study will utilize waste material. The waste material is the cocnut shell ash and coconut shell to strengthen the coarse aggregate bonds, so it is expected to increase the compressive strength along with the increase in permeability. Thus, in this study will replace part of the coarse aggregate with coconut shell with percentage $0 \%, 2,5 \%, 5 \%, 7,5 \%, 10 \%$ and partially replace cement with coconut shell ash with percentage $0 \%, 2,5 \%, 5 \%, 7,5 \%$
\end{abstract}

Keywords: pervious concrete, coconut shell, compressive strength, porosity, permeability

\section{Introduction}

Non-fine concrete can also be called permeaconcrete or pervious concrete, such as concrete formed from mixture of cement, coarse aggregate, water with added material or admixture. Pervious concrete is made with using small amount fine aggregate or even elemenating the fine aggregate.

Weakness of pervious concrete is it's compressive strength tend to low be low. This is due to the cavities in the pervious concrete so it has permeability capability by eliminating the use of fine aggregates on concrete mixtures. However, since there is no fine aggregate filler, pervious concrete does not have a strong enough bond between the coarse aggregates, resulting in a low compressive strength.

In some areas, sometimes it was found difficult to obtain material for the manufacture of concrete. To overcome this problem, this research will be done by using waste that is coconut shell as a partial replacement material of coarse aggregate and coconut shell ash as partial replacement material of cement for mixed material of pervious concrete. In addition, if the use of ash and coconut shells is technically capable of improving the characteristics of pervious concrete, it is also expected to reduce the impact of environmental pollution and have economic value added because the materials used are recycled from waste. Previously coconut shell ash was once applied to conventional concrete and increased the compressive strength of concrete to a maximum at a percentage of cement replacement by $7.5 \%$ (Wardi, 2003). Similarly, the coconut shell is capable of increasing the conventional concrete compressive strength to a maximum of $5 \%$ percentage of coarse aggregate material replacement [1].

In this study will use a combination of ash and coconut shell on a pervious concrete mixture. So it is expected that the use of these materials can increase the compressive strength of pervious concrete which is one of the weaknesses of pervious concrete. In addition to increasing the compressive strength is expected with a combination of a mixture of ash and coconut shell can also increase porosity, permeability, and lighten pervious concrete density.

The purpose of this research are:

a) To find out the compressive strength of a variation of pervious concrete mixture with a variety of replacement materials;

b) To find out the permeability of a variation of pervious concrete mixture with a variety of replacement materials;

c) To know the variations of replacement materials that increase the compressive strength and permeability of pervious concrete. 
The benefit of this research is to obtain pervious concrete with high absorption rate and maximum compressive strength with variation of coarse aggregate replacement material ie coconut shell and cement replacement material variation ie coconut shell ash. It is hoped that pervious concrete results from this research can be applied to light facilities such as the hard drainage layer in the exterior mall area, the surface layer of the park, the floor for the zoo area, and the livestock area.

\section{Research Methods}

\section{A. Material}

The coarse aggregate size used in this study was from $2.5 \mathrm{~mm}$ to $12.5 \mathrm{~mm}$ which is the size of no. 8 in standard ASTM C33. While coconut shell as partial replacement of coarse aggregate to be used used is clean from the flesh and dried in the sun or dried oven. Then the coconut shell is crushed into a small flake with a maximum size of $12.5 \mathrm{~mm} \times 12.5 \mathrm{~mm}$. This is done so that the size of the coconut shell is uniform with a coarse aggregate size.

Cement that used for this study are Portland Cement Composite (PCC) with trademark "Tiga Roda". Coconut shell ash used is the ash of coconut shell combustion and has passed the filter no. 200. From the combustion of coconut shell ie CSA or coconut shell containing silica or $\mathrm{SiO} 2$ compounds, so CSA can be pozolan [2].

\section{B. Steps of Making and Testing Variations of Test Materials}

Calculation of Pervious Concrete Mix Design refers to the calculation of [3]. Samples will be made 6 samples for each variant, and there are 20 variations. So the sample is made as much as 120 pieces of sample as shown in Table 1.

The dimensions of the cylindrical test specimen for the compressive strength test are $15 \mathrm{~cm}$ in diameter and 30 $\mathrm{cm}$ in height. The dimensions of the specimen for density, porosity, and permeability tests are $10 \mathrm{~cm}$ in diameter and $20 \mathrm{~cm}$ in height. The mixture of the specimen will be filled into the mold in 3 layers, each layer will be compressed with 15 times the puncture evenly. After stirring the sample for about 24 hours and hardening, the sample mold will be removed.

Table 1. Variation of Specimen

\begin{tabular}{|c|c|c|c|c|c|c|c|}
\hline & \multicolumn{5}{|c|}{ Persentase CSA } & \multirow{2}{*}{ Total } \\
\hline & & $0 \%$ & $2.5 \%$ & $5 \%$ & $7.5 \%$ & $10 \%$ & \\
\hline \multirow{4}{*}{ 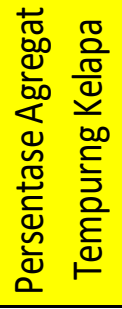 } & $0 \%$ & 6 & 6 & 6 & 6 & 6 & 30 \\
\hline & $2.5 \%$ & 6 & 6 & 6 & 6 & 6 & 30 \\
\hline & $5 \%$ & 6 & 6 & 6 & 6 & 6 & 30 \\
\hline & $7.5 \%$ & 6 & 6 & 6 & 6 & 6 & 30 \\
\hline
\end{tabular}

Then for the treatment of specimens, will be done with curing. Curing method that will be done is to soak the specimen into a water tub. The purpose of curing is to ensure the hydration process that occurs in the concrete.

Before the permeability test it is necessary to calculate its density by weighing the specimen. Next calculate the porosity of the pervious concrete specimen. To calculate its porosity, it is necessary to parameterize the weight of the specimen when it is dry, the weight of the specimen with water, the volume of the specimen and, the density of the water type. Next porosity calculation can be done by using equation that is:

$$
P=\frac{W_{2}-W_{1}}{V o l-\rho_{w}}
$$

Where $\mathrm{P}$ is the total porosity, $\% ; \mathrm{W}_{1}$ is the weight in water, $\mathrm{kg} ; \mathrm{W}_{2}$ is dry weight, $\mathrm{kg} ; \mathrm{Vol}$ is the sample volume, $\mathrm{cm}^{3} ; \rho_{\mathrm{w}}$ is the water density.

The next step is to test the permeability. This permeability test refers to ACI 522R-10 with the falling head permeater tool as shown in Figure 1. Furthermore the calculation of permeability coefficient can be obtained by entering the time data into the Darcy law equation ie:

$$
k=\frac{Q L}{H A t}
$$


Where $\mathrm{k}$ is the permeability coefficient, $\mathrm{cm} / \mathrm{s}$; $\mathrm{Q}$ is the quantity of water collected, $\mathrm{cm}^{3} ; \mathrm{H}$ is the water level, $\mathrm{cm}$; $\mathrm{A}$ is the area of the sample, $\mathrm{cm}^{2} ; \mathrm{T}$ is time, $\mathrm{s}$.

After the permeability test then the next step is a compressive strength test. Compressive strength test will be performed when the specimen aged 28 days with a compressive strength tester.

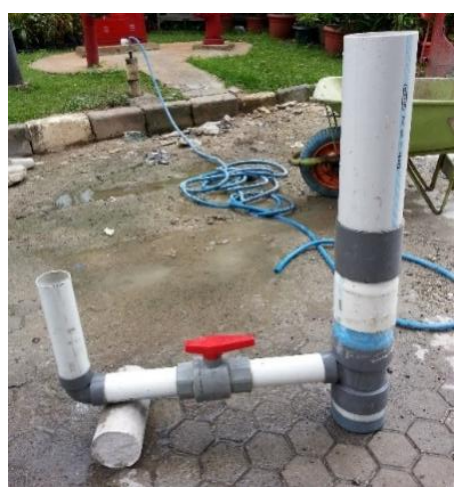

Figure 1. Falling head permeater for permeability test of pervious concrete

(source : research documentation)

\section{Results and Analysis}

\section{A. Proportional of Previous Concrete}

Referring to ACI 522R-10, pervious concrete mix design is a pervious concrete proportional calculation, to find out the need of the pervious concrete material. The material needs of coarse aggregates, cement, and water, as well as replacement materials such as coconut shells, and coconut shell ash, have been calculated and presented in Table 2

Table 2Proportional of pervious concrete mixture

\begin{tabular}{|c|c|c|c|c|c|c|c|c|}
\hline No. & $\begin{array}{l}\text { Coconut } \\
(\%)\end{array}$ & Shell & $\begin{array}{l}\text { Coconut } \\
\text { Shell Ash } \\
(\%)\end{array}$ & $\begin{array}{l}\text { Coarse } \\
\text { Aggregate } \\
(\mathrm{kg})\end{array}$ & $\begin{array}{l}\text { Coconut } \\
\text { Shell }(k g)\end{array}$ & $\begin{array}{l}\text { Cement } \\
(\mathrm{kg})\end{array}$ & $\begin{array}{l}\text { Coconut } \\
\text { Shell Ash } \\
(\mathrm{kg})\end{array}$ & $\begin{array}{l}\text { Water } \\
(\mathrm{kg})\end{array}$ \\
\hline 1 & 0 & & 0 & 1341,00 & 0,00 & 279,2 & 0 & 111,9 \\
\hline 2 & & & 2,5 & 1341,00 & 0,00 & 272,22 & 6,98 & 111,9 \\
\hline 3 & & & 5 & 1341,00 & 0,00 & 265,24 & 13,96 & 111,9 \\
\hline 4 & & & 7,5 & 1341,00 & 0,00 & 258,26 & 20,94 & 111,9 \\
\hline 5 & & & 10 & 1341,00 & 0,00 & 251,28 & 27,92 & 111,9 \\
\hline 6 & 2.5 & & 0 & 1307,48 & 33,53 & 279,2 & 0 & 111,9 \\
\hline 7 & & & 2,5 & 1307,48 & 33,53 & 272,22 & 6,98 & 111,9 \\
\hline 8 & & & 5 & 1307,48 & 33,53 & 265,24 & 13,96 & 111,9 \\
\hline 9 & & & 7,5 & 1307,48 & 33,53 & 258,26 & 20,94 & 111,9 \\
\hline 10 & & & 10 & 1307,48 & 33,53 & 251,28 & 27,92 & 111,9 \\
\hline 11 & 5 & & 0 & 1273,95 & 67,05 & 279,2 & 0 & 111,9 \\
\hline 12 & & & 2,5 & 1273,95 & 67,05 & 272,22 & 6,98 & 111,9 \\
\hline 13 & & & 5 & 1273,95 & 67,05 & 265,24 & 13,96 & 111,9 \\
\hline 14 & & & 7,5 & 1273,95 & 67,05 & 258,26 & 20,94 & 111,9 \\
\hline $\begin{array}{l}15 \\
16\end{array}$ & 7.5 & & $\begin{array}{l}10 \\
0\end{array}$ & $\begin{array}{l}1273,95 \\
1240,43\end{array}$ & $\begin{array}{l}67,05 \\
100,58\end{array}$ & $\begin{array}{l}251,28 \\
279,2\end{array}$ & $\begin{array}{l}27,92 \\
0\end{array}$ & $\begin{array}{l}111,9 \\
111,9\end{array}$ \\
\hline $\begin{array}{l}17 \\
18\end{array}$ & & & $\begin{array}{l}2,5 \\
5\end{array}$ & $\begin{array}{l}1240,43 \\
1240,43\end{array}$ & $\begin{array}{l}100,58 \\
100,58\end{array}$ & $\begin{array}{l}272,22 \\
265,24\end{array}$ & $\begin{array}{l}6,98 \\
13,96\end{array}$ & $\begin{array}{l}111,9 \\
111,9\end{array}$ \\
\hline 19 & & & 7,5 & 1240,43 & 100,58 & 258,26 & 20,94 & 111,9 \\
\hline 20 & & & 10 & 1240,43 & 100,58 & 251,28 & 27,92 & 111,9 \\
\hline
\end{tabular}

From Table 2, the aggregate requirement decreases as the percentage of coarse aggregate replacement with 
coconut shell increases. Similarly, the need for cement decreases as the percentage increase of cement replacement with coconut shell ash. Conversely, the need for coconut shell and coconut shell ash increases as the percentage increases. For water needs are not affected by the percentage of coconut shell or coconut shell ash.

\section{B. Effect of Variation Mixture of Ash and Coconut Shell on Pervious Concrete Characteristic Test Results}

Test results of density test, porosity, compressive strength, and permeability of specimens have been summarized and can be seen in Table 3. Table 3 shows that the increasing percentage of ash and coconut shell use increases the percentage of porosity and permeability of specimens. Conversely, density decreases with increasing percentage of ash and coconut shell use. Increased compressive strength occurs in the use of ash of coconut shell by $2.5 \%$ ie from $4.94 \mathrm{MPa}$ to $7.85 \mathrm{MPa}$, then the compressive strength of the test object decreases. Increased maximum compressive strength occurs in the use of coconut shell with $2.5 \%$ percentage and $0 \%$ ash from 4.94 $\mathrm{MPa}$ to $8.35 \mathrm{MPa}$, then the compressive strength of the test object decreases.

From Table 3, it can be seen also that mixed combination of coconut shell with coconut shell ash did not increase compressive strength. This can be clearly seen in the variation. 7 in Table 3, wherein the compressive strength of the specimen decreases as its porosity increases due to the shrink process of coconut shell material. As a result of the aggregate development process, the dimensions of the coconut shell aggregate increase so as to allow for pressure by the coconut shell aggregate in the mixture during the process of mixing and treating the specimens by soaking. Conversely after the concrete is soaked for 28 days, and dried for a day before the compressive strength test, it is possible to occur aggregate shrinkage due to evaporation of water in the concrete. This will result in the diminution of the aggregate dimensions of the coconut shell and enable the creation of new cavities in the space it occupies during the development process [4]. Therefore it can be concluded that the combination of coconut shell mix with coconut husk ash is not suitable to increase the compressive strength of the specimen.

Generally, as the pervious concrete strength increases, the pervious concrete permeability decreases, and vice versa. However, in increasing the use of coconut shell from $0 \%$ to $2.5 \%$ found the compressive strength of the specimen increases with the increase of permeability. The enhancement of the compressive strength occurred from 4.94 $\mathrm{MPa}$ to $8.35 \mathrm{MPa}$, and increased permeability from $0.382 \mathrm{~cm} / \mathrm{s}$ to $0.417 \mathrm{~cm} / \mathrm{s}$.

Table 3. Data test result of specimen

\begin{tabular}{lllllll}
\hline No. & $\begin{array}{l}\text { Coconut } \\
\text { Shell }(\%)\end{array}$ & $\begin{array}{l}\text { Coconut } \\
\text { Shell } \\
\text { Ash }(\%)\end{array}$ & $\begin{array}{l}\text { Density } \\
\left(\mathrm{kg} / \mathrm{m}^{3}\right)\end{array}$ & $\begin{array}{l}\text { Porosity } \\
(\%)\end{array}$ & $\begin{array}{l}\text { Compressive } \\
\text { Strength } \\
(\mathrm{MPa})\end{array}$ & $\begin{array}{l}\text { Permeability } \\
(\mathrm{cm} / \mathrm{s})\end{array}$ \\
\hline 1 & 0 & 0 & 1754,24 & 17,18 & 4,94 & 0,382 \\
2 & & 2,5 & 1779,7 & 17,82 & 7,85 & 0,38 \\
3 & & 5 & 1696,97 & 18,14 & 5,08 & 0,398 \\
4 & & 7,5 & 1677,88 & 19,52 & 4,18 & 0,403 \\
5 & & 10 & 1673,64 & 19,73 & 3,07 & 0,406 \\
6 & 2.5 & 0 & 1746,82 & 21,85 & 8,35 & 0,417 \\
7 & & 2,5 & 1708,64 & 24,82 & 6,08 & 0,445 \\
8 & & 5 & 1705,45 & 23,86 & 4,9 & 0,449 \\
9 & & 7,5 & 1695,91 & 24,82 & 3,86 & 0,46 \\
10 & & 10 & 1711,82 & 25,14 & 2,67 & 0,465 \\
11 & 5 & 0 & 1737,27 & 25,45 & 4,46 & 0,46 \\
12 & & 2,5 & 1711,82 & 25,45 & 3,67 & 0,46 \\
13 & & 5 & 1639,7 & 26,94 & 3,1 & 0,518 \\
14 & & 7,5 & 1603,64 & 28 & 2,67 & 0,536 \\
15 & & 10 & 1663,03 & 27,36 & 1,56 & 0,527 \\
16 & 7.5 & 0 & 1660,91 & 27,36 & 4,37 & 0,584 \\
17 & & 2,5 & 1616,36 & 28 & 3,26 & 0,589 \\
18 & & 5 & 1610 & 28,64 & 2,82 & 0,594 \\
19 & & 7,5 & 1603,64 & 29,27 & 1,63 & 0,62 \\
20 & & 10 & 1599,39 & 30,12 & 1,24 & 0,639 \\
\hline
\end{tabular}




\section{C.. The Effects of Mixture of Ash and Coconut Shells on Pervious Concrete Characteristics}

a. The effect of ash and coconut shell mixture to density and porosity

The effect of mixture of ash and shell on parameter relation between density with porosity has been presented in graphical form in Figure 2. From Figure 2, it can be seen that the higher the porosity increase, the density will also decrease.

Decrease of specimens weight of the specimen occurs, because of the lightness of the coconut shell as a coarse aggregate replacement material. In addition, as written in a journal entitled "Characteristic Lightweight Concrete Using Coconut Shell as Substitute Aggregate of Coarse" (2010), porosity increase can be caused by coconut shell aggregate development and shrinkage process of coconut shell resulting in changes of coconut shell dimension from mixing to the treatment process speciment.

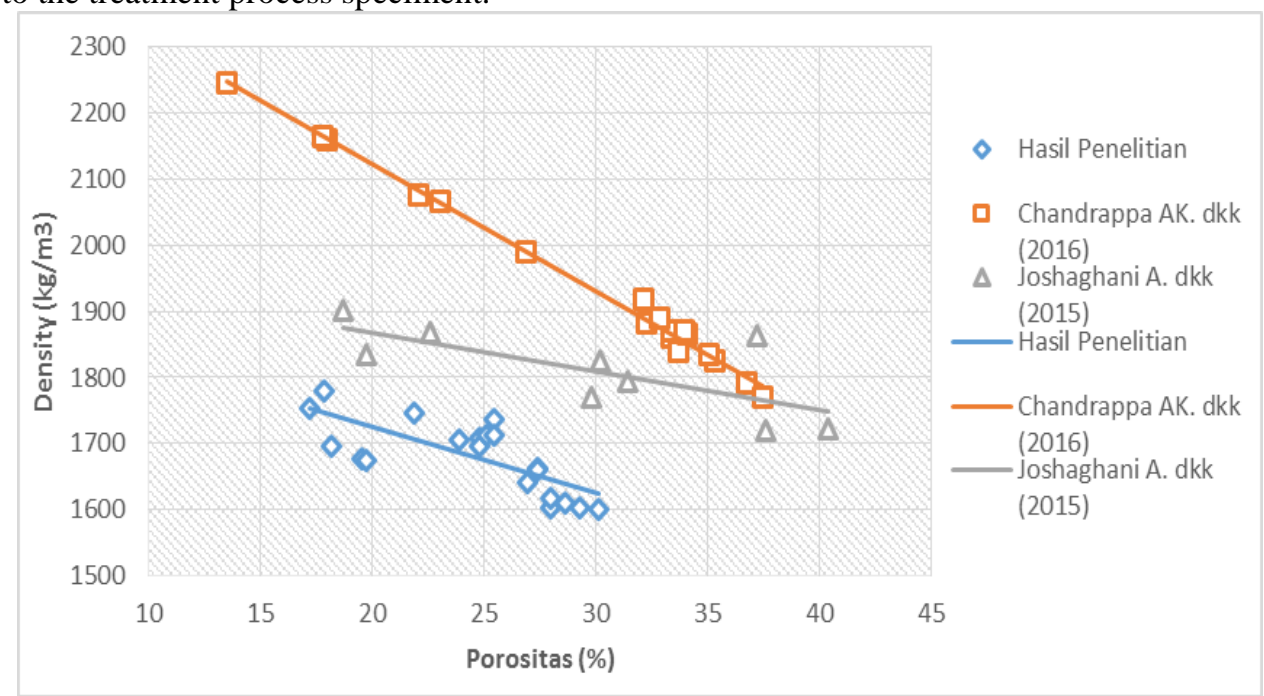

Figure 2. Graph of the relationship between density and porosity

b. The effect of ash and coconut shell mixture to 28 days and density

The influence of a mixture of ash and shell on the relationship between the parameters of the compressive strength of the concrete age of 28 days with the density has been presented in graphic form in Figure 3. From Figure 3, although the degree of slope of the linear pattern is slightly different, but the earlier study with the results still have in common.

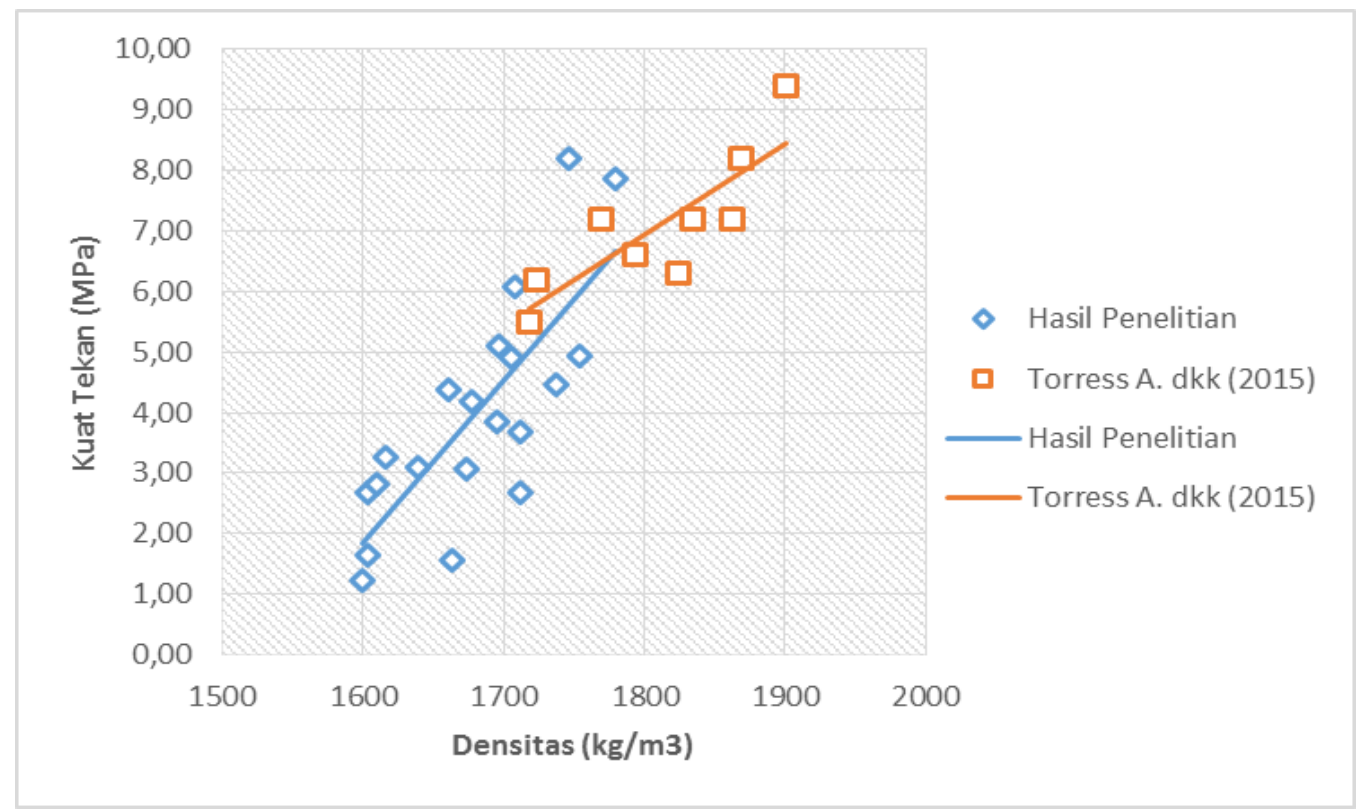

Figure 3. Graph of the relationship between compressive strength and density

The similarity of the respective research that, with increasing density concrete, the compressive strength increases as well according to [3]. The difference, some point to the results of the study have a compressive 
strength similar to previous studies, but the density of research currently tend to be lighter than previous studies. The lighter weight of the research results may be due to partial replacement of coarse aggregates with by coconut shell and partial replacement of cement with coconut shell ash. Due to the coconut shell weighs and the coconut shell lighter than the coarse aggregate weights.

c. The effect of ash and coconut shell mixture to compressive strength and porosity

The effect of mixture of ash and shell on the parameter relation between compressive strength of the concrete age of 28 days old concrete with porosity has been presented in graphic form in Figure 4. Looking at Figure 4, although the degree of slope of the linear pattern is slightly different, but the earlier study with the results still have in common.

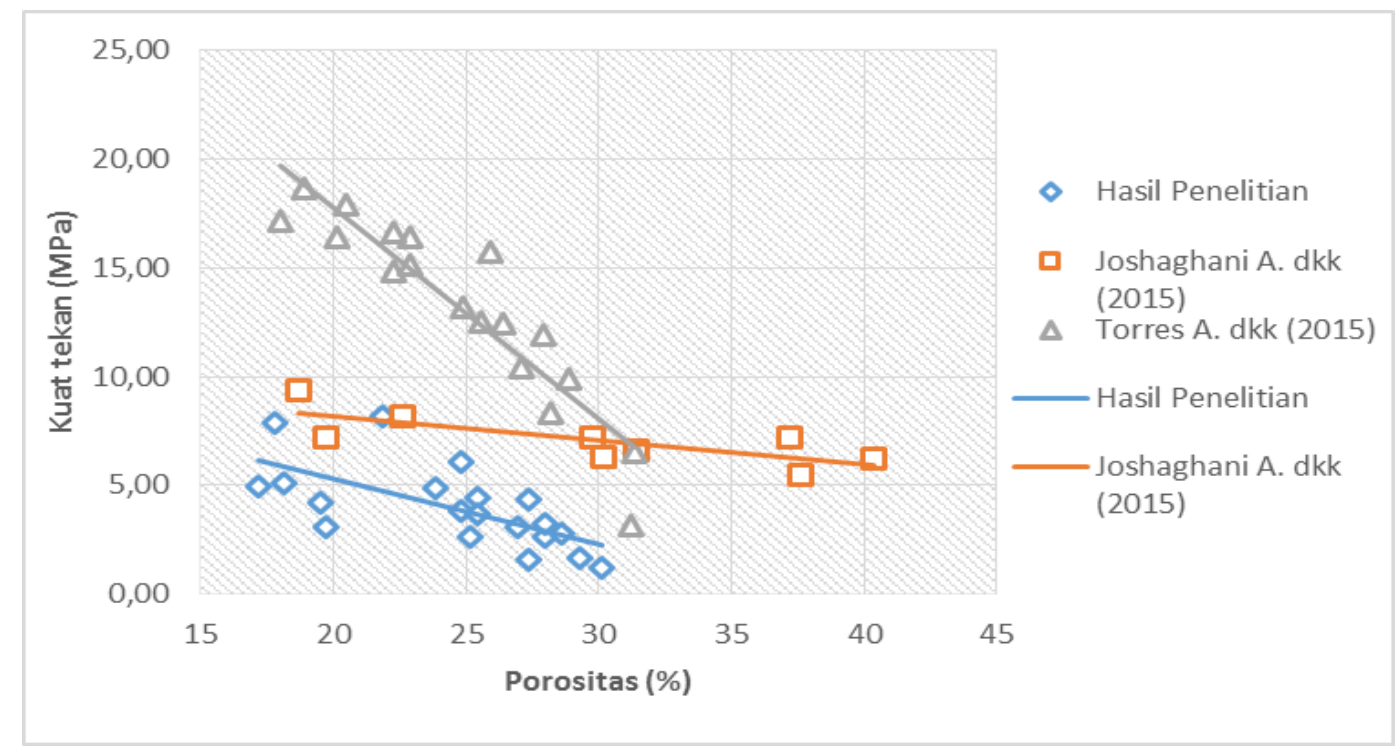

Figure 4. Graph of the relationship between compressive strength and porosity

From the graph of each study in Figure 4, it is explained that the higher porosity, the compressive strength of pervious concrete decrease. [5] obtained results as in Figure 4 because they were influenced by rough aggregate size variations. While [6] obtained the results as in Figure 4 because it is influenced by a variety of coarse aggregate sizes, and the thickness of cement paste.

d. The effect of ash and coconut shell mixture to porosity and permeability

The effect of ash and coconut shell mixture on parameter relation between permeability and porosity has been presented in graph form in Figure 5. Figure 5 shows that the three studies have different degrees of slope of linear line

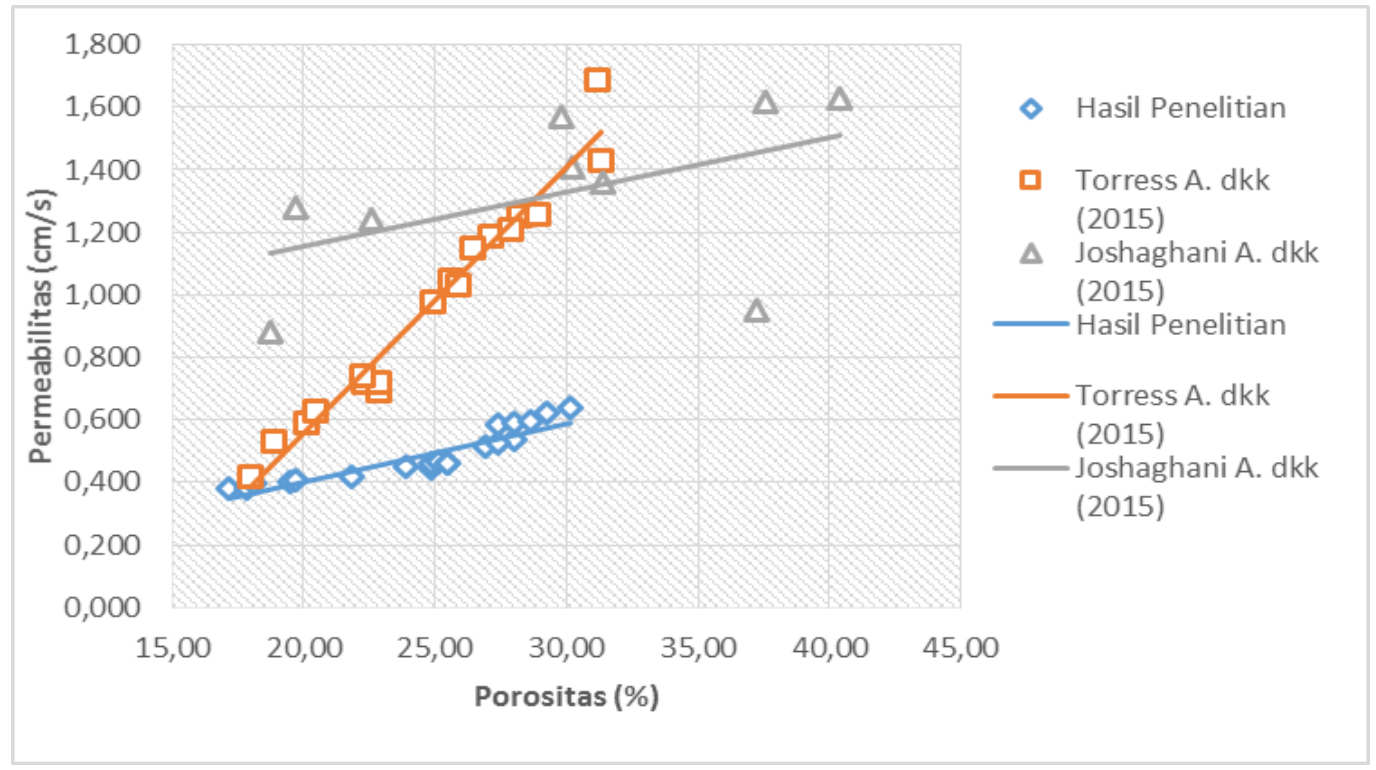

Figure 5. Graph of the relationship between permeability and porosity 
Although each study has different degrees of slope, Figure 5, still shows that the higher the porosity the higher the permeability. Although the percentage of porosity is the same, it does not mean that the permeability is the same. This is because the pervious concrete pores are not necessarily directly connected, so the water does not flow down directly. However, the increase in permeability is affected by the percentage of porosity [3].

e. The effect of ash and coconut shell mixture to compressive strength and permeability

The effect of mixture of ash and shell on parameter relation between compressive strength with permeability has been presented in graphic form in Figure 6. Figure 6, shows that along with increasing compressive strength, porous concrete permeability capability decreases. Likewise, on the contrary, as the increasing of peremability, the compressive strength of pervious concrete decreases. This can be due to the concrete density, where the more dense concrete the percentage of porosity decreases. Because of the low porosity percentage, the permeability will be low [3].

In this study was found, where permeability increases along with the increase in compressive strength. This happens to a combination of a $0 \%$ coconut shell with $0 \%$ ash mixture to a combination of a coconut shell of $2.5 \%$ with $0 \%$ ash mixture. The data of the test results can be seen in Table 3.

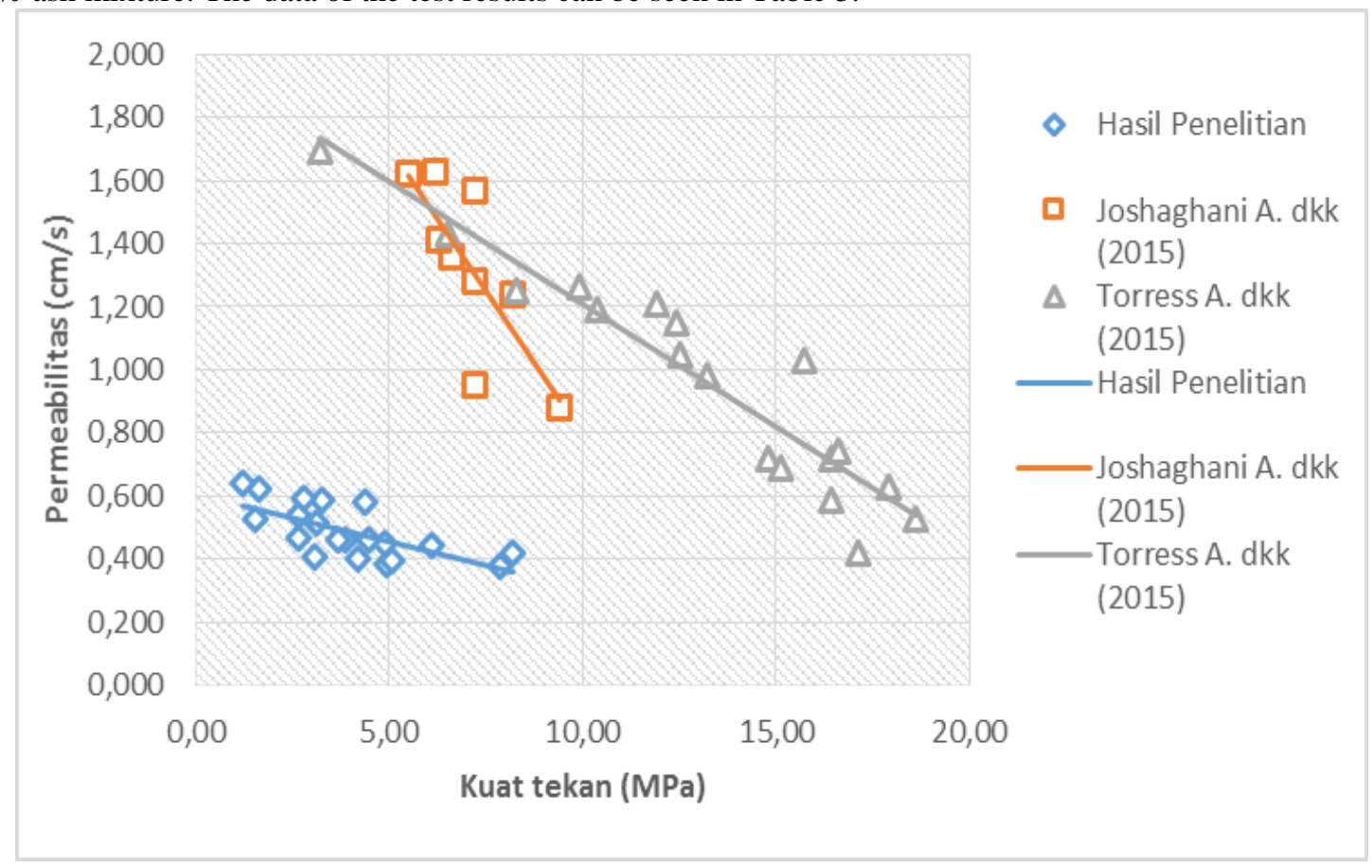

Figure 6. Graph of relationship between permeability and compressive strength

\section{Characteristic of Crack in Speciment After Compressive Strength Test}

Characteristics of cracking of specimens from before until the specimens have been tested for compressive strength will be discussed. In Figure 7 shows the condition of the specimen before the compressive strength test. When testing the compressive strength, the specimens in this study tend to begin to crack in the middle of the test specimen. Figure 8 shows, in the red circle is the cracked model of the specimen when in a compressive strength test the crack starts at the center of the specimen. From the crack, the test object starts to crumble in the middle of the test specimen which can be seen in Figure 9. 


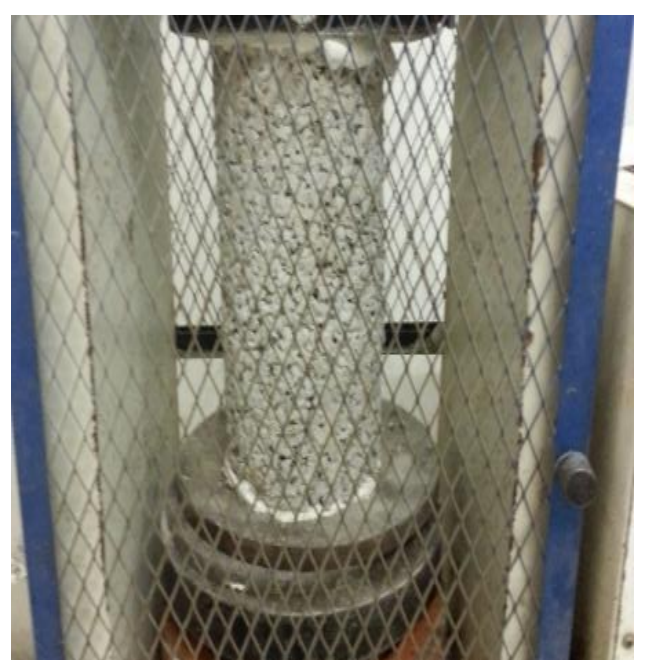

Figure 7. Condition of specimen before being compressive strength test (source : research documentation)

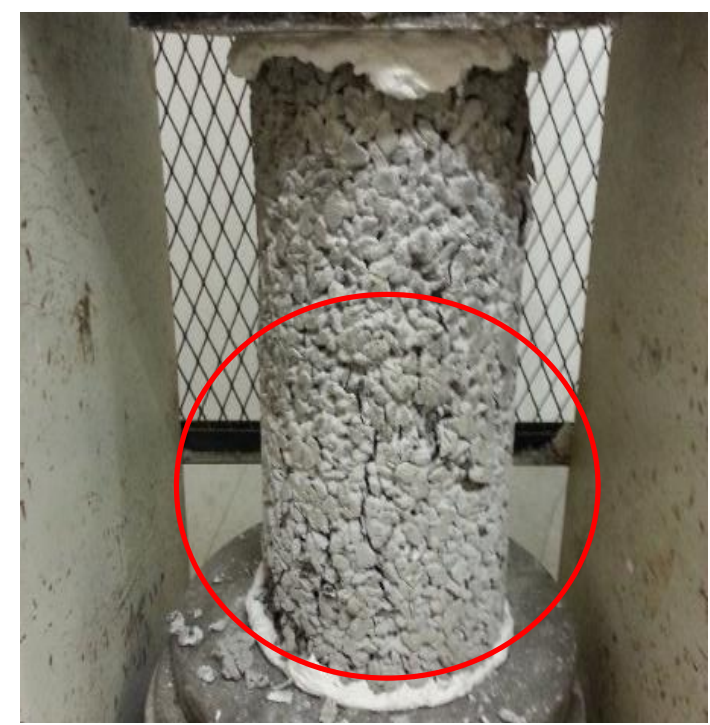

Figure 8. Condition of specimen when being compressive strength test (source : research documentation) 


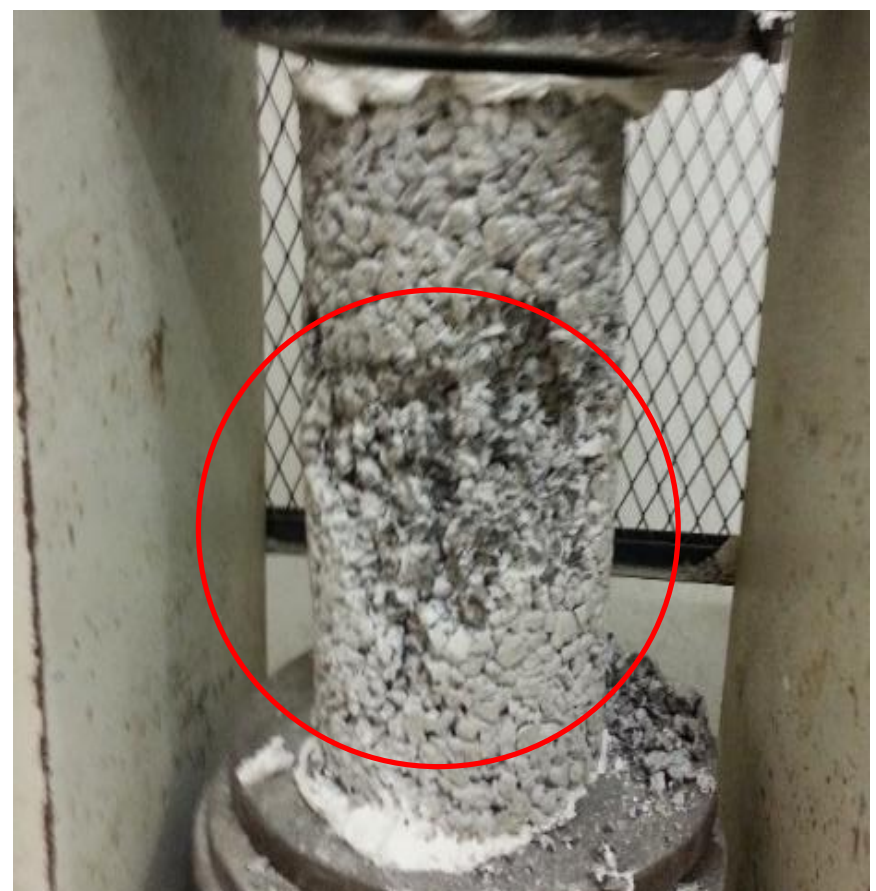

Figure 9. Condition of specimen after compressive strength test

(source : research documentation)

\section{Conclusion}

Based on the results of the analysis in the previous chapter obtained the results of the analysis as follows:

1. Increased compressive strength of pervious concrete by partial replacement of cement with coconut shell ash only occurs in $0 \%$ coconut shell mixture with ash percentage from $0 \%$ to $2.5 \%$ ie from $4.94 \mathrm{MPa}$ to $7.85 \mathrm{MPa}$. Furthermore, the compressive strength decreases in the percentage of shell ash over $2.5 \%$ ie the compressive strength is below $7.85 \mathrm{MPa}$

2. Increased maximum compressive strength of pervious concrete occurs with partial replacement of coarse aggregate with coconut shell of $0 \%$ to $2.5 \%$ without cement replacement with coconut shell of $4.94 \mathrm{MPa}$ up to a maximum of $8.35 \mathrm{MPa}$. Furthermore, the compressive strength decreases in the percentage of coconut shell above $2.5 \%$ ie the compressive strength is below $8.35 \mathrm{MPa}$.

3. As coconut shell and coconut shell ash percentage increase, porosity and permeability continue to increase and density getting lighter.

4. Increased maximum permeability of pervious concrete occurs in variation of partial replacement percentage of coarse aggregate with coconut shell of $7.5 \%$ and partial replacement percentage of cement with coconut shell ash as $10 \%$

5. As the permeability increases, the compressive strength should be decrease. However, in the aggregate replacement variation with the coconut shell percentage of $0 \%$ to $2.5 \%$, the compressive strength increases with increasing permeability. The compressive strength increases from $4.94 \mathrm{MPa}$ to $8.35 \mathrm{MPa}$ and permeability increases from 0.382 to $0.417 \mathrm{~cm} / \mathrm{s}$. After that the compressive strength decreases from the percentage of the shell $2.5 \%$ upwards the compressive strength is below 8.35 $\mathrm{MPa}$, while the permeability increases steadily from the percentage of coconut shell $0 \%$ upwards with permeability coefficient starting from $0.382 \mathrm{~cm} / \mathrm{s}$.

6. The shape of pervious concrete destruction is always brittle, and starting from the center of the test specimen, so the possibility of pervious concrete tension is too weak.

7. Since the probability of pervious concrete tension is too low, it is less suitable to be used as a rigid pavement.

8. Specimen of variation coconut shell mixture $2.5 \%$ and ash $0 \%$ included in the quality of concrete K100, so it can still and suitable for light facilities

9. Combination between coconut shell with coconut shell ash does not match, because it does not increase compressive strength

10. Although the shrinkage of coconut shell aggregates causes enlargement of cavities on the specimen causing a decrease in compressive strength, but on other characteristics increases such as increased porosity, permeability and density getting lighter.

Suggestions that can be given based on this research for further research is as follows: 
1. Research needs to be continued by replacing some of the coarse aggregates with variations in the coconut shell percentage range from $0 \%$ to $4 \%$.

2. Research needs to be continued by replacing part of the cement with a variation of the coconut ash percentage range from $0 \%$ to $4 \%$.

3. Need further research on the use of material variation from research results

4. It is worth trying to variate the smaller aggregate/cement ratio, in order to obtain more dense pervious concrete.

5. To avoid cracks always starting from the center of the pervious concrete, further research is suggested by adding additives capable of strengthening coarse aggregate bonds such as silica fume and the addition of materials capable of strengthening the tensile strength of pervious concrete such as fiber fibers.

\section{References}

F. Akbar, A. Ariyanto, and B. Edison, "Penggunaan tempurung kelapa terhadap kuat tekan betook K-100,” 2014.

V. K. Nagarajan, S. A. Devi, S. P. Manohari, and M. M. Santha, "Experimental Study on Partial Replacement of Cement with Coconut Shell Ash in Concrete,” Int. J. Sci. Res., vol. 3, no. 3, 2014.

ACI522R-10, Report on pervious concrete. Farmington Hills, MI: American Concrete Institute, 2010.

I. W. Suarnita, "Karakteristik Beton Ringan Dengan Menggunakan Tempurung Kelapa Sebagai Bahan Pengganti Agregat Kasar,” 2010.

A. Joshaghani, A. A. Ramezanianpour, O. Ataei, and A. Golroo, "Optimizing pervious concrete pavement mixture design by using the Taguchi method," Constr. Build. Mater., vol. 101, pp. 217-325, 2015.

A. Torres, J. Hu, and A. Ramos, "The effect of the cementitious paste thickness on the performance of pervious concrete," Constr. Build. Mater., vol. 95, pp. 850-859, 2015. 